\title{
THE PASSATIST: LOUIS COUPERUS'S INTERPRETATION \\ OF DUTCH COLONIALISM
}

\author{
E. M. Beekman
}

Louis Marie Anne Couperus (1863-1923) is one of the great writers of Dutch literature and one of its classic novelists. Together with Multatuli, he was an important innovator of Dutch prose, while his inspiration was anything but typical of the prevailing norm. He contributed five masterpieces to the history of the Dutch novel, including The Hidden Force, which doubles as a major work of Dutch colonial literature.

Couperus was of two minds about what he discerned both in himself and in the world at large. He lived among and wrote about opposing forces which seldom responded to conciliation. What is important here are not his attempts as such, but the experience of the dichotomy itself. While awareness of disjunction is almost a commonplace of the romantic imagination, and Couperus was most definitely a romantic, it is also a prominent feature of Dutch colonial letters. One should be able, therefore, to illuminate the general nature of that literature by discussing the specific example of The Hidden Force.

The Couperus family had deep roots in colonial society. ${ }^{1}$ Louis Couperus's great-grandfather, Abraham Couperus, went to the Indies in the latter half of the eighteenth century. While the Dutch still controlled Malacca he acquired a fortune there, and became its governor. He married a local woman from a respected family --Catharina Johanna Koek--whose grandmother was a Malay. After he moved to Java, he continued his impressive career in the colonial Civil Service and became a friend of Raffles, who ruled Java during the British interim regime from 1811 to 1816 .

John Ricus Couperus, the writer's father and Abraham Couperus's grandson, was born in 1816 in the colonial capital, Batavia, and, as was customary, was sent to Holland for his secondary and graduate education. He acquired a law degree from Leyden University and returned shortly thereafter to the Indies, where he embarked on a distinguished career in the colonial judiciary. While living in Batavia he married in 1847 a woman from an aristocratic family, Catharina Geertruida Reynst, whose father had been a vice-president of the powerful Council of the Indies as well as acting governor-general. They had eleven children. John Couperus retired officially in 1862 and went back to Holland to live in The Hague, the city preferred by most retired colonialists. Three children were born there, of whom two died, in addition to one older daughter. The eleventh (and last) child, and fourth son,

1. Biographical information was mainly derived from the following sources: Henri van Booven, Leven en werken van Louis Couperus (1933; reprint ed. The Hague: Bzztôh, 1981); H. W. van Tricht, Louis Couperus. Een verkenning (The Hague: Bakker-Daamen, 1965); Albert Vogel, Louis Couperus (1973; 2d. rev. ed. Amsterdam: Elsevier, 1980); F. L. Bastet, Een zuil in de mist. Van \& over Louis Couperus (Amsterdam: Querido, 1980). 
born one year after his father's retirement, was given the names of his three dead sisters: Louis (after Louise), Marie, and Anne.

Throughout the writer's life, the fortunes of his family remained inextricably tied to the Indies. They owned a coffee plantation in Java, called Tjikopo, and most of Couperus's brothers and sisters spent the greater part of their lives in the tropics. The men maintained the family tradition of pursuing the "gold braid" of colonial officialdom, while the women only married men who were on a social par with their brothers. Couperus wrote later that there were "two brilliancies in Java, two things that bedazzled": the gold of the sun and the gold braid of the Civil Service $(12: 229) .^{2}$ But only he saw a choice between what $E$. M. Forster once specified as the "opposition between two cosmogonies, the spontaneous and the administrative, each with its rival conception of civilization." ${ }^{3}$ Couperus's father was forced to acknowledge that his son would never enter the superior world of the gold braid (7: 534), yet even as a denizen of what was considered the inferior domain of letters, Couperus could never ignore the powerful influence of the Indies.

As the Benjamin in the family of a retire:d and middle-aged father, Louis Couperus grew up in a world of women. From the reminiscences he wrote later in life, one gets the impression that Couperus felt he was an only child $(3: 16)$. Like Forster, he was "royally favoured" ${ }^{4}$ and doted on by his mother and sisters (9: 605). He was a fragile, pampered boy who was constantly fussed over because of his delicate health. Though catered to without much evidence of restraint, he was not allowed to play outside because children of good families never indulged in such a rough pastime, and he had to content himself with a fantasy world to ward off boredom.

Couperus described himself as having been a "weak, soft child" who was quiet and content to be by himself. The male world of his father always "remained somewhat at a distance," while he felt "safe and warm" in the feminine world of his mother, assured "that she would always protect" him. This strong bond with his mother never weakened. After her death he experienced her absence as intensely as he had relied on her presence in his childhood $(7: 666-67)$; one possible reason for his subsequent marriage to his niece was to insure himself of a maternal substitute.

Couperus's father had decided to return to the Indies in 1872, in order to help his grown sons find their way into the official hierarchy and to oversee the family property which was threatened by new agricultural legislation. They lived in a large house on the main square of Batavia (Koningsplein) in a manner far more expansive and opulent than they could ever have afforded in the Netherlands. Couperus was nine when they arrived and fifteen when they returned to Holland in 1878, this time permanently. These tropical years of puberty were crucial to him. It was a happy period. He lived like a princeling in an environment that, both in a physical and in a psychological sense, had more space, was more enticing, luxurious, and sensuous, and offered far more freedom than Holland could ever allow.

2. References for quotations from Couperus's work are given in the text and refer to the collected works: Louis Couperus, Verzameld Werk. 12 vols. (Amsterdam: Van Oorschot, 1952-57).

3. P. N. Furbank, E. M. Forster: A Life (New York: Harcourt Brace Jovanovich, 1978). Pagination is bothersome. This edition is really two volumes, printed together, but with separate pagination. The reference here is to "volume II," $\mathrm{p}$. 221.

4. Ibid., p. 131. 
The resonance of this life was symbolized by the sun, and it never lost its luster for the rest of Couperus's life.

Back in The Hague, the adolescent Couperus proved to be an indifferent student. He failed his exams again and again and his father despaired of his prospects for a career in the colonial Civil Service. The son veered more and more to artistic interests and finally succeeded in acquiring a degree which licensed him to teach literature and language. But he never used it. Instead, he made his literary debut in 1883 with exotically romantic poems, overblown and highly artificial. In 1884, at the age of twenty-one he published his first book, a collection of poems. Four years later he became famous with his first novel, Eline Vere, the story of the demise of an extremely sensitive and overly refined young woman in the upper class milieu of nineteenth century The Hague. Some of the themes in Eline Vere remained constant in Couperus's work, such as the opposition between a refined and lyrical sensibility and the realistic world of practical sense, the imagination versus the lethal weight of quotidian reality, the impasse of loneliness, the delights of passivity, and the inexorable weight of fate.

Louis Couperus was also, of course, a product of his age. In terms of literary history he displayed affinities with the fin-de-siècle literature of the final two decades of the nineteenth century, that concluding episode of literary romanticism also known as "decadence." There is no space here for exhaustive analysis, but one can state with some justification that in his art, Couperus subscribed to notions which, superficially, are said to be typical of "decadence": exoticism, eroticism, aestheticism, deliberate artificiality of style, the glamor of gloom, yearning for a distant past, predilection for legends and myths, and a preference for whatever was illicit at the time. Since we are primarily concerned here with Couperus's predilection for exotic subjects and a distant past, we can profit from Mario Praz's interpretation of the decadent artist. He "transports himself in imagination outside the actualities of time and space" in order to make concrete "an actual former existence in the atmosphere he loves." This is an affirmation of the sensual world, because he invests "remote periods and distant countries with the vibration of his own senses and naturalizes them in his imagination." 5 It is therefore fitting that Couperus liked to call himself a "passatist" $(12: 193)$, a noun he derived from the Italian adverb passato ("the past"), and published novels about Heliogabalus, Hercules, Alexander the Great, Xerxes, about the god Dionysus, about Roman tourists in ancient Egypt and about itinerant actors in first-century Rome, while he also wrote many stories about $G$ reek and Roman subjects.

This "orchid among onions," as one necrologist characterized Couperus, was a man of contradictory impulses. His dissentious life and character resulted in a nonconformist existence, and such characteristics would also seem well-nigh essential for those writers who produced the best of colonial literature. Most of them were mavericks who lived perpetually on the borderline that demarcated the separate worlds of the Indies and the Netherlands. Couperus's restlessness, his exilic life, his hankering for the sun both in a real and in a symbolic sense, his sensuality, his nostalgia, his rueful admission that Asia would always vanquish the West by yielding, his self-contradiction, even his stated pleasure in being a "passatist," all this makes him kin to that line of colonial originals who shared a certain lavishness in their blood. And from the point of view of the average Dutch citizen there would always be something "Oriental" about Couperus the man and about his work. Yet even though Orientalism was a favorite subject of fin-de-siècle literature, Couperus

5. Mario Praz, The Romantic Agony, trans. Angus Davidson (1933; reprint ed. Cleveland: World Publishing Company, 1956), pp. 200-202. 
always maintained that it was an integral part of his personality, not donned like some literary garment. There was something extravagant about him, something resplendent, a voluptuousness that did not fit with a society suspicious of intemperance. It is, therefore, fitting that Couperus's only novel about the Indies was both a masterpiece and considered the first manifestation of his "obscene decadence."

The Hidden Force is based on material that Couperus collected during his second stay in the Indies. The second time he went to that "strange, alluring land of our colonies" $(12: 230)$ he was a noted author and an adult married man who turned thirty-six in Java. He stayed for almost a year, from March 1899 to February 1900. The couple spent the greater part of their Javanese sojourn with Couperus's younger sister Trude, who was married to the resident of Tegal, by name of Valette. When he was suddenly transferred to the more important post in Pasuruan in east Java, the Couperuses followed him. The town Labuwangi in The Hidden Force is a fairly accurate recreation of Pasuruan.

The novel's principal character is the colonial resident Van Oudijck, a fortyeight year old, self-assured, practical, and honest man who takes his executive duty very seriously. He is divorced from his first wife, a woman of mixed blood who is now running a gambling establishment in Batavia and who is the mother of his two children: a son. Theo, twenty-three, and a daughter, Doddy, seventeen. At the time of the novel Van Oudijck is married to his second wife, Léonie, barely thirty, who cares little for her husband or his position. An indolent beauty, Léonie pursues one aim in life: self-gratification, with little regard for moral or social consequences. Unbeknownst to her husband, she is involved in a love affair with her stepson and subsequently proceeds to entice Addy de Luce--a handsome Eurasian about Theo's age--away from her stepdaughter Doddy.

With these main actors, the novel develops two parallel narratives: a domestic tragedy, involving Van Oudijck's response to his wife's infidelities, and a social drama, based on his deteriorating relationship with Sunario, the Javanese regent. Sunario's brother, who is regent of Ngadjiwa, is addicted to gambling and drinking and is in the process of seriously compromising his own position and that of his family. Appealing to the memory of the regent's father, the deceased Pangèran, whom he admired as a close and trusted friend, Van Oudijck warns Sunario that his brother will face dismissal if he does not reform. When the regent of Ngadjiwa still does not alter his ways, Van Oudijck dismisses him, refusing even to give in to pleas for mercy from Sunario's mother. From that day on inexplicable events happen, such as, for instance, Léonie being spat at with red juice when she is alone in her bathroom (or kamar mandi) taking a bath, or Van Oudijck discovering that his bed has been soiled and his whiskey polluted. In private, the Dutch official finally confronts his Javanese counterpart (whom he suspects of being the instigator of the strange events) and congratulates himself at having achieved at least a moral victory.

But to no avail. Léonie's profligacy worsens. Anonymous hate mail informs her husband of her depravity, while Addy makes sure that Theo, his rival for Léonie's affections, meets Si-Oudijck, purportedly Van Oudijck's illegitimate son and thus Theo's half brother. The hate mail engenders jealousy, hatred, and disorder among the people living in the residency. Van Oudijck slowly succumbs to dissolution and retires to the interior of Java, where he spends the rest of his years living with a native mistress in her village. Doddy marries Addy and goes to live with the wealthy De Luce family at their compound in Patjaram, and Léonie removes herself to Paris to indulge her licentiousness. 
Among the various minor characters, Eva Eldersma is probably the most important. She is the Dutch wife of the district secretary, a man who has become more of a bureaucratic machine than a human being. Eva is educated, cultured, and far better suited to be Van Oudijck's wife than Léonie. Her parties are Labuwangi's main social events and are the equivalent of those the resident's wife should herself give. Eva also understands Van Oudijck's basic decency far better than anyone else. But she too is "defeated" by the "hidden force" and returns to Holland as a disillusioned but far wiser person.

Couperus modeled Resident Van Oudijck's more admirable traits on those of his brother-in-law, Valette, who was a respected official; Trude engendered the greater part of Eva Eldersma; Léonie was based partly on his wife's grandmother; and even the Léonie-Addy-Doddy triangle seems to have been inspired by an incident from the paternal past of Couperus's family.

Valette taught his brother-in-law a great deal about the life and responsibilities of a high colonial official (12:230), but, as Couperus repeatedly emphasized, the supernatural element of the book had nothing to do with Valette. It has been suggested that the governor-general who was then in power--Van der Wijck, who was related to Couperus's wife--gave him access to an official document that dealt with the same kind of events that were described in the novel, and which were alleged to have taken place in 1831 in the house of Assistant-Resident Van Kessinger in a town called Sumedang. The report described a rain of stones that fell inside the house for sixteen days and had been witnessed by a celebrated general of the colonial army, A. V. Michiels, who was not known for his gullibility. A report of what had happened was submitted to the ad interim governor-general, J. C. Baud. In a book published in Java in 1926, a certain Dr. Baudisch reviewed a number of similar occurrences that took place in Europe and concluded that what happened in Labuwangi were poltergeist phenomena. ${ }^{6}$ This pertains to the stone throwing, sirih spitting, hammering on the ceiling, the soiling of Van Oudijck's bed, the glass shattering in his hand, and his whiskey turning yellow. The sobbing souls of little children in the waringin tree, and the appearances of the white hadji are of a different nature.

Couperus has been criticized for not being entirely accurate about the supernatural events in his novel; and it has been said that, like many other Dutch colonials, he had no real sympathetic understanding of the world of the Javanese. I cannot entirely agree with this assessment. First of all, such poltergeist phenomena as are described in the novel did take place from time to time, and some had been witnessed by sober and incredulous Europeans. Secondly, magic and mysticism were part and parcel of everyday life in Java. This is still true today. ${ }^{7}$ That in Java black magic (klenik) and mysticism (kebatinan) are not entirely distinct can be ascertained from Sukarno's injunction in 1958 that practitioners of kebatinan

6. A Baudisch, Het probleem van de "Stille Kracht" (Weltevreden: Kolff, 1926), pp. $13,61-70,112$.

7. Javanese mysticism is a large topic. In the few selected texts given below one will find my argument corroborated. For contemporary mysticism and religion see: Niels Mulder, Mysticism and Everyday Life in Contemporary Java (Singapore: Singapore University Press, 1978), and Clifford Geertz, The Religion of Java (1960; reprint ed. Chicago: University of Chicago Press, 1976). For a survey of, and the background for, the bewildering variety of mystical groups see: Harun Hadiwijono, Man in the Present Javanese Mysticism (Baarn: Bosch \& Keuning, 1967). 
should be careful not to let it turn into black magic. ${ }^{8}$ Similarly, the practice of tapa, or asceticism, can endow the practitioner with the powers of black magic, but it can also lead to the "revelation of the mystery of existence." 9 No matter who or what one consults, there is a general consensus that in Java, past and present, "the relationship between nature and supernature is so intimate that it is impossible to draw a line; both participate in the oneness of existence, and ordinary objects may contain the signs and powers of the all-encompassing cosmic process." "Nature and supernature mutually influence each other, and causality is implied in their coordination. When co-ordination happens or is brought about, events and conditions have to follow. This thinking is valid for both pure mysticism and for magic; moreover, it is valid for one's personal life, for the condition of society, and the perception of history." 10 Mind and matter are far more readily conceived as adversaries in Occidental thought, and when the latter does entertain itself with irrational forces, it is, more often than not, a momentary diversion with droll toys. Couperus suggests this opposition in narrative fashion when the European dabblers, to relieve their boredom, can manage nothing better than table turning, while Java's "hidden force" overwhelms rationality and the phenomenal world.

Couperus was susceptible all of his life to the influence of irrational forces. Two decades after writing The Hidden Force he confessed:

Yes, I believe in the evil power of datura flowers; I believe that there are elmus, ${ }^{11}$ I believe that benevolent and hostile forces float around us, right through our ordinary, everyday existence; I believe that the Oriental, no matter where he comes from, can command more power over these forces than the Westerner who is absorbed by his sobriety, business, and making money. Sometimes, when I look deeply into the eyes of a Javanese or Malay, one instant longer than I normally would, then I not only believe but I know that, if he is friendly disposed to me and despite racial differences, he can cause something favorable, or, if he hates me, something unfavorable to happen to me. And I feel this so strongly that I am amazed when I hear the jovially gainsaying horselaugh of him who thinks that he has a lease on wisdom and, naive Westerner that he is, wants to explain the entire antique soul of the East that is suffused with mystery by means of a positivistic cavil. (12: 470-71)

That the supernatural was a common manifestation of life in the Indies was already demonstrated in Couperus's time by $\mathrm{H}$. A. van Hien in his study, De Javaansche Geestenwereld en De betrekking die tusschen de geesten en de zinnelijke wereld bestaat [ The Javanese Spiritworld and the Relationship that exists between the Spirits and the World of the Senses]. ${ }^{12}$ This, to my knowledge the only work

8. Mulder, Mysticism and Everyday Life, p. 5; Hadiwijono, Man in the Present, p. 236.

9. Mulder, Mysticism and Everyday Life, pp. 24, 23-25, 33-34.

10. Ibid., p. 17.

11. Elmu is more commonly spelled ilmu in Malay and ngelmu in Javanese. It is the general term for "knowledge" and in combination with other words can refer to both what we call science and the occult sciences. The Datura flower is Datura fastuosa, from the family Solanaceae, known in the Indies more commonly as katjubung. It is a plant about three feet tall, with spiky fruit and large white or purple flowers. Flowers, seeds, and leaves are said to be poisonous. The white flowers are considered the most poisonous, and the purple ones (katjubung merah or itam) less so.

12. 4 vols. (Semarang: van Dorp; Bandung: Fortuna, 1896-1913). 
of its kind in Dutch, was published in four volumes between 1896 and 1913, and it would seem likely that Couperus knew of this unique examination of Javanese spiritism, explained by Van Hien with sympathetic understanding. In the first volume, published in 1896, Van Hien describes three (among eighty-five) negative spirits, whose behavior bears some resemblance to incidents in the novel. For instance, the gendruwa or gandarwa is described as a garden or forest spirit that manifests itself by "throwing stones and other objects on the roofs of houses, spitting at or besmirching a person, animal, or other objects, with red sirih-juice, knocking on doors and windows, or shaking them."13 This would concur with the poltergeist phenomena mentioned before. In the fourth volume, published in 1913, Van Hien discusses a malevolent force called djihin, which he translates as "a devilish power, a silent or secret force," using Couperus's phrase here, "stille kracht," which is the Dutch title of The Hidden Force and which, to my knowledge is original with Couperus. Van Hien explains that there are "formulae" a Javanese can use to incite this djihin and which "have the power to plague the inhabitants of the designated house with incessant throwing of stones, spitting suru [i.e., sirih], throwing filth, knocking on doors and windows. . . And what person has not heard of such mysterious stone throwing and suru spitting, which is often mentioned in newspapers, that presents so many problems to the police, and which at first was attributed to malevolence but which in the final analysis had to be ascribed to a mysterious force. There is not a single Javanese who doesn't know how those mysterious vexations are evoked, but he will rarely speak of it because he's afraid to incite the displeasure of the spirits and he thinks it best to play dumb when confronted by Europeans." 14

Invocation of djihin can be said to be the source of the supernatural events in the residency. Nor is this to be confused with the Javanese version of sorcery, or guna-guna, which Couperus never refers to. Given Couperus's predilection for such irrational powers, it seems likely that he would have wanted to keep the nature of the hidden force undefined, suggestive. But the novelist saw that he needed concrete instances for his tale, and so he included them for narrative and dramatic reasons, all the time careful not to reveal their provenance. In other words, Couperus used paranormal events that were plausible within the context of his narration and from the point of view of a Dutchman. Couperus does not display this spiritism from the viewpoint of the Javanese--an impossible task that would have been prone to distortion and misunderstanding. He wisely refrained, and presented incidents of occultism in the novel as particular occurrences experienced by Europeans, or as topics of gossip and rumor. To be sure, there are intimations that the regent is involved, but nowhere is that firmly established as proven fact. If it had been, it would have destroyed the unique atmosphere and power of the novel, would have reduced it to a confrontation between a skeptic and a magician, would have cheapened the awe that the "hidden force" should elicit, and trivialized Van Oudijck's tragedy. And tragedy depends on a feeling of inevitability to demonstrate the uncertainty of our lives and of our world. In The Hidden Force this is represented in psychological terms by the inevitable penalty for denying the power of the libido, in symbolic terms by the fated triumph of Asia over Europe, and in metaphysical terms by the inescapable juggernaut of fate.

Fate is the central force of Couperus's work. No matter how rich his imagination, his occasional detours into caressing fantasy, his irony, or fits of ecstasy, Couperus remained convinced of the immutability of the law of mankind's impotence

13. Ibid., $1: 13$.

14. Ibid., 4: 34-35. Suru is the Javanese word for sirih. 
in an indifferent universe. Although he presented it in many different ways, Couperus seldom gave this law a precise label, except for an early and indifferent novel entitled Noodlot (1891) which means "fate" in Dutch. In a mythic allegory entitled The Sons of the Sun (De Zonen der Zon; 1903) which remained a personal favorite with Couperus, it is presented by a turning wheel; in a similar text called Jahve (1903) it is "Secret"; in one of his masterpieces, Of Old People the Things that Pass (Van oude mensen de dingen die voorbijgaan; 1906) it is simply "the Thing": in the present novel it is a "hidden force"; in Iskander it is "Asia"; in The Books of the Small Souls (1901-1903) one of its manifestations is the same somber force of heredity that also ruled naturalism.

Not surprisingly, Couperus often associated fate with fear and the night. He distinguished being afraid ("bang zijn") from fear ("Angst") : "when one is afraid, one is afraid of something or someone. . . . But when one knows Fear, that Fear is felt as a mystery . . . like a mysterious threat of what will be or happen . . . " (8: 377). Night, which "has always given me a certain vague fear," is its preferred time, though Couperus also felt a reverence for it because there was "something holy" about the night. Despite its demonic potentiality, night can also bring consolation, offered by its "solicitous maternal hands." In other words, the night is woman (7: 696-97). In The Hidden Force, the night is described as soft, pliant, lax, and velvety; it "dissolves thinking . . . leaving only a warm sensuous vision" that arouses an "inexorable hankering for love."

The Hidden Force is a nocturnal book; most of its major scenes take place at night. Announced in the opening sentence, the novel's titular deity is the moon, the lunar symbol of the female force of life. The moon is red, foreboding disaster and the exercise of supernatural power. Couperus noted later in Eastward that the tropical moon of the Indies was "always something of a magic mirror" for him (12: 349). In symbolic terms, the novel presents the struggle between the lunar night and the solar day. One representation of the lunar night is the ubiquitous "hadji." Except for the final scene, the "hadji" is only seen at night, of ten by moonlight, and only by women. He is expressly identified as a ghost by Urip, the Javanese maid. Van Hien describes a spirit called antu-darat who lives most often at the foot of old trees and who goes out at night "in the shape of and dressed like a hadji." 15 The solar day is the province of Western authority, and is represented by the resident's ceremonial pajong (or golden sunshade) that is described as a "furled sun." But in this novel the female lunar world of intuition, imagination, and magic, triumphs over the male solar world of reason, reflection, and objectivity.

Van Oudijck is surrounded by the female force, not only as the symbolic power of Asia, but psychologically also by the instinctual drive for immediate gratification. This is most clearly represented by his second wife, Léonie, his daughter Doddy. and his son Theo, and by Addy de Luce. One has to keep in mind that in 1900, when this novel was published, the egoistic sexuality of this quartet was shocking, while Léonie was at the time an uncommon character in Dutch literature. Couperus drew such a convincing portrait because she reflected certain aspects of his own personality. Though this "white sultana" with her impervious "milky white creole languor" was born in Java of European parents, she is more Indies than Dutch. ${ }^{16}$ Her complacent sexuality is a form of narcissistic indulgence, fueled by her vanity, and protected by her indifference. Like a tropical Venus, Léonie is beyond the

15. Ibid., $1: 15$.

16. The word "creole" did not necessarily refer to people of mixed blood who were born in the Caribbean. In Couperus's time it simply indicated people who were born in the tropics, though of European parents. 
moral ken of society; her indifference is well-nigh superhuman, and she is called invulnerable because "destiny does not weigh on her."

Such an embodiment of pure carnality should not be fecund, and it is noted that Léonie does not have children. Yet one cannot consider her truly evil because, like an animal or a flower, she is sufficient unto herself and never seriously troubled by a superego that would insist on standards and ideals. Hence it is not surprising, either psychologically or symbolically, that Léonie is devoid of intellect. Her passing in society is a momentary epiphany that is swiftly gone. Her tastes are adolescent, the private life of her mind is devoted to advertisements and trivia, and it is fitting that her most representative lovers are young males living a prolonged adolescence. Typically, when Léonie is confronted with a choice between Theo and Addy, she simplifies it by reducing them to physical types, thereby ignoring the notion of individuality. To have used more rational methods would have been inconceivable for this embodiment of sensuality. That she is inviolable is demonstrated by the fact that, when fate comes to exact its retribution, Léonie's punishment is a form of superficial pollution that, literally and figuratively, can be washed off.

Ironically, the impressive scene in the bathroom is far more charged with sex than any other, because for once Léonie's almost inert sensuality is enlivened by the kinetic energy of terror. Sensuality needs specificity to become sexual, and Léonie's languid sensuality that, though yielding, never gives in, is for the moment shocked into unaccustomed reality, and finds itself obscene. Like a frightened adolescent she runs for safety to her surrogate mother, her maid Urip. But her punishment for what are, after all, palpable trespasses, is finally little more than succumbing to the virus of jealousy, which in the end infects the entire household of the resident. As a result, the indulgence of a love goddess becomes tawdrily human, as if a reflection of her crude imaginings. Her illicit trysts, for example, are no longer enjoyed with regal nonchalance in her boudoir, but in the seedy hut of the pandering Mrs. Van Does. And Léonie now also admits to the fear of old age; aging, with its physical deterioration, pollutes her timelessness.

Addy de Luce is Léonie's twin, except for the saving grace of his Javanese blood. He is even less mentally endowed than the resident's wife, though he too needs only to be physically present in order to be loved. He has the animal vigor and grace of a tiger, as Eva Eldersma also noted about Van Oudijck's wife, but Addy is even more godlike than his older and female complement. His prototype was Dionysus, the god Couperus celebrated in his first mythological tale, published in 1904. Addy de Luce is called a "beautiful, southern god," "a devastating young god," an "unthinking god." This "tempter" (in the original capitalized as "Verleider") has a "Moorish face" and there's "something southern and seductive," "something Spanish" about him. Addy shines with physical perfection due to the "harmonious" blending of a Gallic adventurer and a Javanese princess. Brainless, hence unchecked by rational control, Addy is both insatiable and uninhibited--perhaps even more so than Léonie.

The De Luce family is described as being quintessential Indies. Yet even here is a link with Léonie, because the way the De Luces are described would fit her as well, as if she were one of their children. It is a family that shows "a great simplicity of mind . . . together with an unbounded weariness and tedium, a life of no ideas and but few words, the ready, gentle smile making good for both."

Theo Van Oudijck also combines European and Javanese blood, but in no way as harmoniously as Addy. Big and blond, Theo looks like his father, yet in him, too, the blood of the Indies will assail Van Oudijck. Just as lazy and indifferent as his stepmother, his sister, and Addy, Theo Van Oudijck purposely avoids work and duty as if to insult the Protestant ethic of his father. He quickly succumbs to the 
spell of his rival Addy, and just as rapidly surrenders to Si-Oudijck, his father's alleged illegitimate son. This is not surprising of someone who is described as "a blond native" or, what amounts to the same thing, a "fat blond sinjo," whose Indies blood is prominently featured in his sensual mouth, and who considers himself the son of his Indies mother and not at all his father's child. His sister. Doddy, looks like her mother and, at seventeen, is sexually mature. Thus literally and figuratively, Van Oudijck is surrounded by an alien world. Both in his domestic world and the larger arena of society and history, he is as inescapably enmeshed in a net of ruin as was Agamemnon. And in Java, too, the net was cast by the feminine element. His children, for instance, remain "secretly faithful to their mother," Van Oudijck's first wife. She lives from gambling, and gambling is a passion, hence something Van Oudijck abhors. And to be sure, gambling is the vice which destroys the regent of Ngadjiwa who, indirectly, proves to be the undoing of Van Oudijck. In this fashion Couperus keeps on insinuating unobtrusive connections between the world of woman, passion, and Java.

The distinctive nature of the male and female spheres of influence is kept quite clear. Van Oudijck is repeatedly upheld as a paragon of masculinity, with its attributes of reason, logic, work, duty, and pragmatism. He is described as a robust, virile man, blessed with "fine human qualities," who is "simple and practical" and "temperate," altogether an impressive person because of his "masculine simplicity." But due to these very same virtues, Van Oudijck is also incapable of admitting to complexity, nuances, to involution or to paradox. In his willful denial of life's complexity, coupled with his genuine desire to be of service, Van Oudijck is an attractive embodiment of paternalism, and in his domestic tragedy, his paternal arrogance and inflexibility constitute a tragic flaw reminiscent of King Lear. But the novel extends the conflict to the level of society and history, making Van Oudijck, as resident of Labuwangi, also represent the paternalism of colonialism. Couperus then suggests another dimension to Van Oudijck's principles. His desire for the clarity of an ordered existence is outworn and no longer viable, not even in the strict world of the Javanese aristocracy. In his sorrowful affection for the regent's father, the dead Pangèran, Van Oudijck, like his creator, betrays himself to be a "passatist" who, to his dismay, finds his present reality becoming increasingly confusing and contradictory. That reality belies his faith in life's certitude. The power of what Van Oudijck always considered weakness--with its attendant connotations such as unpredictability, doubt, confoundment, insecurity, indefiniteness-comes to undo him with a ferocious insistence that baffles him. Used almost like a Homeric epithet, formlessness gathers shape and strength, like an incremental repetition, until it has overwhelmed the protagonist.

One of the novel's symbolic correlatives for what is rationally so difficult to define, is the anonymous hate mail that Van Oudijck begins to receive. The aspect of it that he most dislikes is its vagueness, a characteristic that is also a major element of the "hidden force." The hate mail is said to originate--though that too is kept vague--with Van Oudijck's illegitimate son, Si-Oudijck. The scene where, at Addy's instigation. Theo and his supposed half brother finally meet combines the domestic and the official paternalism of the novel: the two young men are delighted with the prospect of destroying Van Oudijck both as a father and as a high colonial official.

Si-Oudijck represents the dark or nocturnal side of Van Oudijck's personality, his unconscious. He presumably engendered this depraved offspring when still a minor official in Ngadjiwa, the same region that is now presided over by Sunario's younger brother. Si-Oudijck lives in a kampong, the Malay word for a native village. But for the Dutch colonialists "living in the kampong" also meant "going native" in the sense of coming down in life, of surrendering to a dissolute element that was supposedly synonymous with native life. When his fortune is at a low ebb, 
Van Oudijck gives in and sends money to his supposed bastard, "that miserable thing in the kampong" and winds up living in a similar village himself with his "new little family ... [that is] a typical Indies mess."

In the novel, the kampong also represents sexuality. It is where Si-Oudijck was conceived, where Tidjem (Addy's babu) lives who gives Addy the use of her hut for his nocturnal assignations, and where Addy has his rendezvous with Léonie. And out of the kampong night comes the "venomous libel" which, like Léonie's "vermillion pollution" is "spewed forth from quiet corners," "bespattering and besmirching" the colonial hierarchy. The accusations are mostly of a sexual nature, and are associated with nocturnal forces: they represent a stealthy and "mock battle in the dark." The libel, the kampong, and the tropical night, combine to suggest the id, wherefrom the unconscious energy flows represented by sexual craving.

Van Oudijck's demise must come from this nocturnal world of passions and sexuality. But this is only possible because he is susceptible to it. In a little kampong near Garut in western Java, he admits to Eva that he cannot live without a woman. The revenge of the archetypal world of woman is manifested in Van Oudijck's uncharacteristic surrender to irrational, blind jealousy. He is consumed by this elemental, instinctive force which usurps the dynamism of his masculine paternalism and makes it impossible for him to do his work. This irrational emotion is the translation of the supernatural events into affective energy that is without form, unbridled, and dangerous. The entire residency is infected by this virulent disease of jealousy and hatred, directed primarily at Léonie. Having lived an imbalance, Van Oudijck must now suffer its inevitable punishment, the unleashing of "untamed and untameable psychic power."17 The moral blackmail that was posted in the kampong night, directs his mind to the perverted sexuality of his wife, destroys his rational control so that he comes to believe in ghosts and supernatural events, and finally estranges this usually so self-possessed man from his own identity. The climate begins to affect him, his health is undermined, and his skin turns yellow, like his "ochred whiskey." Having succumbed to the hidden force, Van Oudijck also falls victim to its generally indistinct, obscure mode of behavior. The benighted resident comes to vacillate, hesitate, "to muffle anything that was too sharp with half measures." Now that both body and mind are mollified, Van Oudijck comes to resemble Léonie when he gives in to "the gentle weakening of his muscles and the aimless drowsiness of his thoughts." He has no ambition left, the vertical "hierarchical line of the Civil Service" declines to the tranquillity of horizontal repose; the resident has submerged himself in a "lukewarm indifference" that was formerly associated with Léonie. Like his second wife, who always runs away from trouble, Van Oudijck finally slinks away from Labuwangi and his responsibilities and hides in the heart of Java, a heart that was once said to be unconquerable. There the retrogression of his "ascending line" is completed when he confesses his revulsion for colonialism to Eva Eldersma.

The Eldersmas reflect Van Oudijck's duality. Onno, the husband, is the hypertrophied version of the masculine devotion to work. When the resident has become an emotional vagabond, Onno adds his superior's work to his own, already inhuman, load. But it is without reward. His enslavement to the administrative grind dehumanizes him, and he returns to Holland a broken man. Eva represents the ethical side of Van Oudijck. She appears to be the only person who understands that there is more depth to his character than most people would allow. One should also note that Eva, a Dutch woman, would have made the perfect complement for Van Oudijck

17. C. G. Jung, Four Archetypes (Princeton: Princeton University Press, 1970), p. 38 . 
because she combines in her person the practical and the aesthetic. Eva is not superficial or indifferent like Léonie; she supports her husband and is faithful to him, and she cares for the world and is not trapped in the prison of egoism, as Léonie is. In societal terms, her house is the "real" residence, and she brings life to Van Oudijck's existence and to provincial Labuwangi.

Because Eva is almost Van Oudijck's alter ago, she foreshadows his fate. Although she shows that the Dutch could do a great deal of good, the same charitable instinct goes awry when she forces her maid Saina to accept her patronizing good will. She is resented for it because the Dutch woman fails to comprehend even the simplest Javanese. It is also fitting that the hidden force's first assault on Eva's Western enthusiasm is executed by nature. She is the only one who can respond to the majesty of Java's nature, and she is vulnerable to attack because of her aesthetic sensitivity. The monsoon rains ruin not only the beauty and grace of the "artistic consolation" of her carefully contrived environment, but they also rot and mildew her soul. Couperus fuses Eva's physical and intellectual demise in the fine image of the warped piano that is out of tune because of the humidity and the insects.

It is also by means of Eva that Couperus insinuates that the hidden force is not only Java or triumphant Asia but also the power of "the other." In a deliberate parallel with the novel's opening scene, Eva, like Van Oudijck, is standing at the foot of Labuwangi's lighthouse. Staring into the night she becomes aware of her "humiliating littleness, as of atoms," "of small people at the foot of the little lighthouse [ while] overhead drifted the fathomless immensity of the skies and the eternal stars. And from that immensity drifted the unutterable, as if it were the superhumanly divine, wherein all that was small and human sank and melted away." Compared to the power of this ineffable relentlessness, Eva's "line of grace and beauty" or Van Oudijck's "ascending line" are rather pathetic aspirations.

Only one character in The Hidden Force exhibits what may be considered the correct response to such fatalism. She is Urip, Léonie's personal maid, whose name means "life" in Javanese. While Theo and Léonie shudder with fear when they hear the souls of little children sobbing in the waringin tree, Urip "squatted low, humbly, as though accepting all fate as an inexplicable mystery," "patient and resigned under the big and little things of life." But none of the other characters show a similar acceptance.

Even Van Oudijck's adversary, the regent Sunario, is really an instrument of this same inevitability. Sunario is only described from the outside, fashioned into a shape from the collective reactions of the resident and other people. All that Van Oudijck knows about the regent is gleaned from rumors. The regent is like an idol wherein resides the strength of his nation, or like the image of a deity that by virtue of its inscrutable power remains unsullied by the pollution of a foreign and ignoble presence. Couperus's interpretation of the paradoxical nature of the Indies is also present in the regent. He is called "a saint and a sorcerer" who harbors, despite his physical delicacy, an ominous forcefulness that is akin to the slumbering energy of his volcanic homeland. Even in this implacable Javanese aristocrat who does not allow Van Oudijck any purchase on his character or soul, Couperus has maintained the multiple levels of meaning we have been pursuing. This "enigmatic wajang puppet" has a "feminine air" about him, while his secret rage is described as identical to the controlled fury of his mother, the Raden-Aju. His only animated features are his eyes. What they convey is a power Couperus liked to associate with Asia: a paradoxical strength of aggressive passivity that can destroy its victim without any overt or cognitive means. Van Oudijck's practical sobriety has no defense against such an elusive and irrational power. 
The clash between the regent and the resident has been interpreted as the fulcrum of Van Oudijck's tragedy. Such an interpretation went far to rescue this novel from the critics who wanted to dismiss it as a tale of exotic hocus-pocus. But one remains uneasy. From a psychological viewpoint, one could call Van Oudijck's defeat tragic, but only in the general sense of causing sorrow or sadness. The resident's denial of his psyche's anima will have serious consequences, for no man is whole who lives to the exclusion of the woman in him. On a symbolic level, Couperus seems to suggest that the masculine Occident will in the end not succeed when it tries to conquer the muliebral world of the Orient. But I think that what Couperus intended to convey might go beyond either position.

Walter Kaufmann once perceptively noted that Hegel proposed a dissenting opinion of what made Greek drama tragic. In Kaufmann's words, Hegel realized "that at the center of the greatest tragedies of Aeschylus and Sophocles we find not a tragic hero but a tragic collision, and that the conflict is not between good and evil but between one-sided positions, each of which embodies some good." 18 This is, 1 think, what is at the core of The Hidden Force. One must remember that Van Oudijck is a decent human being who is brought low by an error of judgment, not by vice or depravity, and whose main objective in life is to labor for the amelioration of the Indies.

Both Van Oudijck and Sunario have responsibility commensurate with their respective positions. Neither is entirely wrong and both embody some good. Nor is either man diminished by guilt. What 1 think is the irony of their respective positions is that both want only what they deem best for the populace. The Raden looks forward to the prospect of a Java ruled by the flower of its own poeple, while the resident envisages a Java ruled by a select elite of the usurping Western nation. To achieve his vision Van Oudijck believes in the necessity of enforcing progressive measures to improve the welfare of the overseas territory, while for the Javanese nobleman it means defending the sacred trust that history bestowed on his lineage in governing his realm according to a divine right that does not need an alien sanction. Both positions would have profited from a mutual comprehension of what would be beneficial for a common good, yet both will remain blind to the best efforts of their adversary because they are not of the same blood.

The "tragic collision" of the resident and the regent can now also be viewed from the larger perspective of the opposition of East to West, of A sia to Europe. one remembers that the creative soil which nurtured Couperus's imagination was fertilized by the late nineteenth century, one will discover that the foundation for the larger opposition is the perennial fascination of the northern European for the southern world of the Mediterranean. Like E. M. Forster, Couperus found his personal and artistic salvation in Italy, the country where, to quote Forster, "they say 'yes' . . and where things happen."19 If one extrapolates from this celebrated and, according to Thomas Mann, fatal duality, it is not difficult to find parallels in such archetypal pairs as reality and art, the rational and the intuitive, the masculine north and the feminine south, or, indeed, the Occident and the Orient. An additional ramification is to view the first as the realm of the father and the latter as the realm of the mother. The paternal realm--exemplified in Couperus's case by his judicial father--is characterized by order, duty, intellect, consciousness, and the disunion of subject and object (i.e., Van Oudijck), while the maternal realm--Couperus's indulgent, loving mother--is typified by license, sensual gratifi-

18. Walter Kaufmann, "Hegel's Ideas about Tragedy," in New Studies in Hege/'s Philosophy, ed. Warren E. Steinkraus (New York: Holt Rinehart, 1971), p. 202.

19. Furbank, E. M. Forster, 1: 96. 
cation, intuition, the unconscious, sexuality, and unity. Quite apart from the relative merit of each sphere of influence, it seems to me that this constitutes the symbolic core of colonial literature.

Asia represents the realm of the mother, and, as if underwriting Bachofen's theory of mother right, Couperus indicates her supremacy in several works of fiction. 20 In The Mountain of Light it is the grandmother Julia Moeza who, as the Magna Mater from the Asian East (Syria in this case) presides as the most potent force over the life of her grandson, the Emperor Heliogabalus. In Of Old People the Things that Pass three generations are blighted by a crime committed by the grandmother. As a young woman, grandmother Ottilie murdered her husband with the help of her lover during a stormy night in Java. Like a generational radiation, that lethal passion and its indomitable agent, rules the vast family, particularly dominating the males. In The Hidden Force, the De Luce family is ruled by the grandmother, while Van Oudijck's fateful confrontation with the "hidden force" is really enacted between him and Sunario's mother, when the resident behaves to her almost as if a supplicant son.

This also applies to Couperus's final masterpiece, the novel Iskander. The title is the Asian name for Alexander the Great and is the eponym of various Islamic dynasties. Similarities with Couperus's colonial novel include the fact that this work, too, is ruled by the lunar and nocturnal world of the great goddess, and that its victorious power is as indistinct as the Javanese one. Couperus adds a third dimension to the symbolism of the feminine principle: the ocean. Alexander wants to vanquish both "India and the Ocean, that land of magic and that worldwater [sic]" (11: 631). This is the ocean of the collective unconscious, the third realm of the great goddess as the lunar Isis, Ishtar, or Aphrodite Anadyomene, and also the ocean of time.

Alexander never reached India. He was overpowered by the same forces he had vanquished. He is defeated by Asia, the feminine principle, and one of her instruments is the eunuch Bagoas--an androgynous figure like Couperus's favorite god Dionysus--who, like Sunario, wants to avenge Asia not by killing Alexander but by seeing him waste away morally. Like Van Oudijck, Alexander also comes to know his defeat. Standing next to the plundered tomb of Cyrus, Alexander knows why he returned, unnecessarily, to Asia. "Never would his mouth confess that, even though he had conquered Asia. Asia had conquered him and had known how to drip into his body and soul the secret poison of her silent and enduring Revenge, into the body of him who was still so young, barely three and thirty years. But he knew it, and he knew that, like the least of his own soldiers, he was exhausted from this immense greatness and this superhuman victory" (11:653).

The initial reason asserted by Couperus for Alexander's desire to conquer Asia is identical to the one Hegel indicated in his lectures (from the third decade of the nineteenth century) on The Philosophy of History: "It was Alexander's aim to avenge Greece for all that Asia had inflicted upon it for so many years, and to fight out at last the ancient feud and contest between the East and West. "21 Couperus would also agree with Hegel that "Alexander's expedition to Asia was at the same time a journey of discovery." 22 For Hegel this meant no more than disclosing

20. See J. J. Bachofen, Myth, Religion, \& Mother Right, trans. Ralph Manheim (Princeton: Princeton University Press, 1973), pp. 69-120.

21. G. W. F. Hegel, The Philosophy of History, trans. J. Sibree (New York: Dover, 1956), p. 272.

22. Ibid., p. 273. 
the Oriental world to Europe, while for Couperus it meant a confrontation of the self with "the other," of the individual with time, of the male with the female archetype of existence. Yet Hegel also thought of India as the "land of imaginative aspiration, a Fairy region, an enchanted World" that was possessed of "an Idealism of imagination." He compared the Asian subcontinent to a beautiful woman in a passage that is peculiarly seductive. India, as the "Land of Desire," is equated with Nature. Hegel clearly comprehended the heartland of Asia as feminine and allowed it great power, yet he managed to turn these characteristics--which I can only comprehend as positive--into a negative denunciation. ${ }^{23}$

Before Hegel's time, Asia's seductive lure was already a basic motif in Western antiquity, something that Couperus was well aware of. For instance, Aeschylus's Agamemnon decries the effeminate luxury of things Asia, while Euripides's last play, The Bacchae, describes the god Dionysus as being distinguished by feminine beauty, to have Asia as his provenance, and the Great Mother goddess (Rhea or Cybele) as his ally. For Couperus, Dionysus symbolized the liberation from the northern world of the father by his insistence on the hegemony of the southern realm of the mother. Dionysus as Lusios, or "the Liberator," prefigured the liberating indulgence in more "irrational impulses," such as his imagination, his emotional ambivalence, the femininity of his nature, or his "Orientalism" which Couperus, from the very beginning of his career, claimed to be uniquely his own and not acquired by literary proxy. Dionysus incorporates all of these aspects; he is a hybrid god, ${ }^{24}$ both Asian and Hellenic, with hermaphroditic traits. This "Zeus of women" is said to have conquered the Near East and to have overwhelmed Asia as far as, and including, India--a feat Alexander was said by Couperus to have wanted to emulate. Dionysus's mother was the lunar goddess Semele, while his grandmother was the Great Goddess, the Magna Mater, Rhea.

Dionysus's dual nature was essential for Couperus's interpretation of the god. In the dozen sonnets prefacing his mythic tale about Dionysus, Couperus confessed for the first time to his bilateral soul, that was both "a child of northern woe" and a participant in a jubilee of blue, Mediterranean skies $(4: 541)$. But he also extended to Dionysus the ability to overcome disunion by incorporating opposites, and Couperus has the god very tenderly rehabilitate the melancholy loneliness of "Hermafroditos," the antique misfit who was both the male offspring of Hermes's "radiant intellect," and the female offspring of Aphrodite's "radiant beauty" (4:625).

These constantly overlapping sets of opposites which were so important to Couperus's personality and art, are also fundamental to colonial literature, and it is therefore fitting that a writer who experienced duality as keenly as Couperus did would create a classic fiction of the cultural schism between East and West. But was there also a way of overcoming this dilemma? In terms of Couperus's lifelong devotion to his art, that consolation can be found in the act of creativity itself, where he fused narrative insight with lyricism. Yet once again, this, too, can be expanded to include the other pairs of opposites we have been trying to isolate.

The convergence of the two opposing principles in the act of literary creation was symbolized for Baudelaire by the thyrsus: the staff, topped by a pine cone and entwined by vines, that is representative of the cult of Dionysus. In one of his inimitable prose poems ("Le Thyrse"), Baudelaire equated the staff with the masculine will and the embracing vines with the feminine imagination. "The flowers

23. Ibid., pp. 139-42.

24. Carl Karényi, The Gods of the Greeks (1951; reprint ed.: Harmondsworth: Penguin, 1958), p. 221. 
are the promenade of your phantasy around your will; it is the feminine element performing its enchanting pirouettes around the masculine one. Straight line and arabesque line, meaning and expression, the will's rigidity and verbal sinuosity, unity of goal, variation of means. . . ." 25

This would parallel the division at the core of colonialism and colonial literature. In The Hidden Force, Hegel's prose world and Baudelaire's masculine "straight line" correspond to the "ascending line" or the "hierarchical line of the [colonial] Civil Service" of the European paternal world of administrators. Baudelaire's feminine "arabesque line" and Hegel's poetic India correspond to Eva Eldersma's "line of grace" and "line of beauty." In the light of colonial society Eva's husband, Onno, typifies the prose world of the dull administrative drudge, while Van Helderen, the man she feels attracted to, is more in tune with Eva because he can "work toward a beautiful goal but not . . . for the sake of work and not [in order] to fill the emptiness of [his] life." "Beautiful goals" are, of course, anathema to the colonial hierarchy, and Van Helderen's superior, Resident Van Oudijck, warns Eva to be careful with the likes of Van Helderen because "he puts too much literature into his monthly reports."

But what is a shortcoming to Van Oudijck, is from Couperus's point of view a virtue. Hence it is Van Helderen who explains to Eva that the Indies has a prose as well as a lyrical side. The latter he finds in its people, its past, and in its nature, while the prose is represented by "a gigantic but exhausted colony. "It is ironic that Couperus endowed Eva with the conscious awareness that both "lines" should exist side by side, ironic because she is an outsider who will return to Europe as a disillusioned woman. Yet it is she who is aware that she has a practical side that can see through the prosaic absurdities of the European community, and an "exotic side" that is able to perceive "what was really poetic, genuinely Indies, purely Eastern, absolutely Javanese." That essence is represented by both the "noble majesty of nature" and by the elegance, grace, and "aristocratic distinction" of the Javanese.

Addy De Luce is the paradigm of such physical grace, but it is an enigmatic beauty that combines perfection from both sexes. He radiates in the flesh what his name connotes, while one can even wonder if his name also contains a lexical echo of "lusios," the previously mentioned epithet of Dionysus. That Couperus wanted to establish a connection between Addy and Dionysus is clear from the number of positive similes that compare him to a Mediterranean deity. For that matter, his entire family is generally referred to in a positive fashion. Addy inherited his grace and elegance from his Javanese mother, and his grandmother is treated by Sunario's brother, the regent of Ngadjiwa, with the respect normally granted only to Javanese royalty. Couperus indicates that the De Luce family has managed to preserve the best of Indies society, such as its elaborate customs, its generous hospitality, and the emotional security of an extended family. They are unencumbered by the malaise of European introspection due to their lack (from a European viewpoint) of a stimulating intellect. But Couperus also notes their lack of greed and their simple bonhomie that makes them the only social unit in the novel that lives in peace and harmony.

The description of life in Patjaram, the family compound of the De Luces, comes close to representing a tropical utopia. For Doddy, for instance, Patjaram is an ideal world, where brown is the preferred color of distinction and white one of derision. Patjaram also represents the abundance of life, and its fecundity should be

25. Charles Baudelaire, Oeuvres Complètes, "Bibliothèque de la Pléiade" (Paris: Gallimard, 1961), p. 285. My translation. 
contrasted with the barren beauty of Doddy's stepmother, Léonie. "For Patjaram was her ideal of what a home should be. The big house, full of sons and daughters and children and animals, who were all subjected to the same kindness and cordiality and boredom, while behind those sons and daughters shone the halo of their Solo heritage." And as if to emphasize Patjaram's distinction, Doddy refers to it as "the ideal residence," something that Van Oudijck's colonial seat of power clearly wasn't.

Presided over by a benign materfamilias, Patjaram's vital élan should be contrasted with the colonial capital of Batavia which is described as a city of the dead, oppressed by "the white burden of mortality." Its European inhabitants live unaware of the surrounding beauty of tropical nature, and human interaction has been reduced to the disembodied intercourse of telephone conversations. In Batavia, white is the color of death, while in Patjaram brown is the color of life and health.

Patjaram's world is the world of the "Indo," the Eurasian. For Couperus it seems to have represented a successful combination of the Oriental and the Occidental strains precisely because he saw it as a racial consolidation. It must be remembered that, like the Dutch colonials, the noble family of the Adiningrats is also in decline, a deterioration personified by the regent of Ngadjiwa who debases both himself and his ancient class. The grandeur of their lineage seems to have been reduced to an all-consuming hatred for the European usurper, an enmity that leaves no room for either vigor or conciliation. This emotional paralysis is not shared by the De Luce family, though it is linked to the glory of the Adiningrat's past by "the halo of their [mutual] Solo heritage." The link with Europe is by way of their paternal founder, a French aristocrat down on his luck who exploited his culinary skills to ingratiate himself to high Javanese society. One can't help but feel that Couperus was poking fun at European imperialism by reducing its pretensions to the level of a kitchen. But the De Luce family is clearly meant to have benefited from the two racial adversaries by amalgamating them into a mellow intermedium that softened both stringencies.

That the harmonious blending of "the blood of the Solo princess and that of the French adventurer" should be promulgated with figurative allusions to Mediterranean culture, is consistent with our previous discussion of Couperus's symbolism. As was mentioned before, when Couperus looked back on his childhood in the Indies, he knew that he had benefited from its solar ardor in order to mature both physically and psychologically. But he also realized that he had found an alien sun in Java, one totally different from the memorial sun of antiquity that could warm the heart and mind of an avowed passatist. "Now that I love I taly I know that, even though the Indies enraptured me because of its sun, even though the Indies returned to me the South wherefrom I had been mysteriously banished, I missed the Latin South, and I know now why then, in the Indies, an oleander was dearer to me than a flamboyant. . . There was the sun, and there was the South, but a South without emotion and without memory, and yet I was the child of parents [living] in the Indies" (7: 671).

This modulation of the symbolic solar power, this preference for a cultural temperate zone, is present in The Hidden Force in Couperus's covert predilection for the Eurasian world of Patjaram. There is a tragic irony in Van Oudijck's professed hatred of the "Indos," as the Eurasians were then called, who people that world, for all his children belong to the group. In the eyes of Van Oudijck, however, people of mixed blood are racially desultory, as indistinct as the "hidden force" itself. He is at ease with clear entities such as Europeans or Javanese, and genuinely wants the best for both in a world that the passatist knows to be reliable and 
unequivocal. But in the reality of the present he finds a bewildering uncertainty, with the "Indos" indicative of the liberality of change. ${ }^{26}$

Though said to be unable to aspire to intellectual supremacy, Patjaram is a world of physical beauty and grace. For Couperus and his age such a world was something of an Eden that was greatly preferred to a bloodless civilization that was choking on braindust. That graceful physicality is symbolized by Addy's dancing that is compared to "a dream upon the water. This came to him with his mother's blood, and was a survival of the grace of the srimpi $i^{27}$ among whom his mother had spent her childhood, and the mingling of what was modern European with what was ancient Javanese, gave him an irresistible charm."

This final instance might be the best example of how a personal psychology infused a symbolic pattern, which in turn imbued a cultural position. Couperus's surreptitious partiality for Eurasian society would have been unpopular in his day. The Eurasians were to become the truly dispossessed people of colonialism, an invisible society that was excluded from everything but the periphery. ${ }^{28}$ The final irony of The Hidden Force is that, while hiding from his colonial past in western Java, Van Oudijck does not see that he has been granted a measure of solace by living like the society he tried so hard to deny.

26. It is not surprising that in the domestic parallel, Léonie wants to make love to "both white and brown" while Doddy desires to have only brown children with Addy.

27. Srimpi, more commonly spelled serimpi, was a female choric dancer at a royal Javanese court, most often at Solo (or Surakarta) or Yogyakarta in central Java.

28. See J. Th. Koks, De Indo (Amsterdam: Paris, 1931), esp. pp. 249-67. 